\title{
Combining Ability and Gene Action Studies for Yield and its Component Traits in Bread Wheat (Triticum aestivum L.)
}

\author{
Parthik U. Patel*, B. C. Patel, Mayank P. Sidapara and Deepak D. Sharma \\ Regional Research Station, Anand Agricultural University, Anand-388 110, Gujarat, India \\ *Corresponding author
}

\begin{tabular}{l} 
Ke y w o r d s \\
Mean squares, \\
Lines and testers, \\
Combining ability \\
\hline Article Info \\
\hline $\begin{array}{l}\text { Accepted: } \\
18 \text { April } 2020 \\
\text { Available Online: } \\
\text { 10 May } 2020\end{array}$ \\
\hline
\end{tabular}

A B S T R A C T

Analysis of variance for combining ability revealed that mean squares due to lines and testers were significant for all characters, indicated contribution of both lines and testers towards the general combining ability variance. The mean squares due to lines $\times$ testers were also significant for all the characters under study, which revealed the contribution of hybrids for specific combining ability variance component. This indicated involvement of both additive as well as non-additive components of gene action. The potence ratio $\left(\sigma_{g c a}^{2} \sigma_{s c a}^{2}\right)$ was below unity for all characters, which revealed preponderance of non-additive gene action in inheritance of all characters under study.

\section{Introduction}

Wheat is one of the major staple food crops in the world, being consumed from ancient times by human beings. Wheat is being cultivated on more than $17 \%$ of cultivable land and consumed by nearly $40 \%$ of the global population occupying about $32 \%$ of the total land under cereals in the world. Wheat fulfils $21 \%$ of the protein requirements of more than 4.5 billion people in developing countries (Braun et al., 2010). India is the major contributor to the world wheat production after China, witnessing a tremendous increase in production during last four decades. India accounts for an area, production and a productivity of 30.60 million hectares, 98.38 million metric tonnes and $3216 \mathrm{~kg} / \mathrm{ha}$, respectively (Anonymous, 2018).

Information regarding general and specific combing ability enables the plant breeder to evaluate parental material and to decide a suitable breeding procedure for maximum improvement in yield and component traits. Line $\times$ Tester in one the approaches for 
estimating the combining ability of newly developed lines or germplasm lines. The analysis enables one to understand the nature and magnitude of gene action involved in inheritance of component characters. The present investigation was undertaken to study the combining ability of the lines for yield and associated traits.

\section{Materials and Methods}

Combining ability and gene action studies for grain yield and its component traits was carried out at Regional Research Station, Anand Agricultural University, Anand. The experimental material consisted of 67 genotypes, comprised of five lines (GW 496, GW 322, GW 366, GW 451 and GW 11), ten testers (GW 480, GW 492, GW 498, VA2015-11, VA-2015-41, Lok 73, GW 504, GW 499, GW 500 and VA-2015-34) and their 50 hybrids.

Crosses were produced by mating the parents according to Line $\times$ Tester mating design by taking lines as seed parent and testers as pollen parents. The experimental material was evaluated in Randomized Complete Block Design with three replications. Each plot consisted of single row of $2.5 \mathrm{~m}$ length. The inter and intra row spacing was $20 \mathrm{~cm}$ and 10 $\mathrm{cm}$, respectively. Package of practices for cultivation was followed as per agronomical recommendations.

The observations were recorded on twelve different characters viz. days to $50 \%$ heading, days to maturity, plant height, number of effective tillers per plant, length of main spike, number of spikelets per main spike, 100-grain weight, grain yield per plant, biological yield per plant, harvest index, protein content and hectolitre weight. The recorded data were subjected to analysis to assess combining ability of parents and their hybrids and gene effects.
The analysis of variance for combining ability was carried out as per method suggested by Kempthorne (1957) and reviewed by Panse and Sukhatme (1978). The Line $\times$ Tester analysis is analogous to North Carolia Design II of Comstock and Robinson (1952).

\section{Results and Discussion}

The analysis of variance revealed that considerable amount of variation existed among the lines, testers, parents and hybrids for most traits under study.

The analysis of variance for combining ability revealed that mean squares due to lines and tester were significant for all characters under study, which denoted prime importance of lines and testers in contribution toward the inheritance of traits and general combining ability component of variance.

Mean square due to line $\times$ tester was significant for all characters, which revealed contribution of hybrids towards specific combining ability component of variance.

The magnitude of sca variance was higher than gca component of variance for all the characters under study, which indicated preponderance of non-additive gene action in inheritance of the characters under investigation. Potence ratio $\left(\sigma_{g c a}^{2} / \sigma_{s c a}^{2}\right)$ revealed same results for all characters.

Estimates of general and specific combining ability were estimated for parents and crosses, respectively. Results revealed that none of the parent was found good combiner for all the characters.

All characters were found under the influence of non-additive gene action, as reported by Mandal and Madhuri (2016). The results for individual character are discussed as follows. 


\section{Days to $50 \%$ heading}

For this character, lines GW 366 (-2.04) and GW 451 (-2.01) and testers, GW $492(-2.61)$ and GW $498(-1.21)$ were found as good combiners as they possessed significant and negative estimates of gca effect. In case of sca effects, total 14 crosses possessed significant and negative estimates. The estimates of $s c a$ effects ranged from -4.49 $(\mathrm{GW} 366 \times \mathrm{GW} 499)$ to $5.77(\mathrm{GW} 366 \times \mathrm{GW}$ 492).

\section{Days to maturity}

Analysis revealed that lines, GW 451 (-5.22) and GW 366 (-5.03) and testers, GW 492 (4.32) and GW $498 \quad(-3.03)$ possessed significant and negative estimates of $\mathrm{gca}$ effect. Estimates of $s c a$ effects ranged from 7.07 (GW $11 \times \mathrm{GW} 504)$ to 8.17 (GW $366 \times$ GW 492). 13 crosses exhibited significant and negative $s c a$ effect for this trait.

\section{Plant height}

In case of plant height, lines GW 451 (-2.96) and GW 366 (-1.75) and testers, GW 480 (7.07) and GW 500 (-4.32) were found good combiners. Among the crosses, estimates of sca effects ranged from $-14.55(\mathrm{GW} 451 \times$ GW 504) to 9.23 (GW $451 \times$ VA-2015-11).

\section{Number of effective tillers per plant}

For number of effective tillers per plant, lines GW 451 (0.83) and GW 496 (0.69) and testers GW 499 (2.07) and GW 492 (1.87) possessed significant and positive estimates of $g c a$ effect and considered as good combiners. Estimates of $s c a$ effects ranged from -2.66 (GW $322 \times$ GW 504) to 4.47 (GW $366 \times$ GW 504).

\section{Length of main spike}

Lines GW 496 (0.54) and GW $322(0.40)$ and testers GW 499 (0.78) and VA-2015-41
(0.55) exhibited significant and positive estimates of gca and were classified as good combiners. Estimates of $s c a$ effects ranged from -1.45 (GW $496 \times$ VA-2015-11) to 2.46 $(\mathrm{GW} 496 \times \mathrm{GW} 499)$. Total eight crosses possessed significant and positive estimates of $s c a$ and hence were classified as good specific combiners.

\section{Number of spikelets per main spike}

In case of number of spikelets per main spike, lines GW 322 (1.95) and GW 496 (0.13) and testers VA-2015-41 (1.84) and VA-2015-34 (1.40) were found good combiners. In case of sca effects, the estimates ranged from -3.20 $(\mathrm{GW} 496 \times$ Lok 73 ) to 2.88 (GW $322 \times \mathrm{GW}$ 499) among crosses. Twelve crosses possessed significant and positive estimates of sca effect.

\section{0-grain weight}

For 100-grain weight lines GW $366(0.23)$ and GW $451(0.22)$ and testers GW 492 (0.34) and GW 499 (0.34) were found as good combiners. Estimates of sca effects ranged from $-0.57(\mathrm{GW} 11 \times \mathrm{GW} 492)$ to $0.56(\mathrm{GW}$ $496 \times$ GW 499). Total twenty five crosses exhibited significant estimates of sca effects of which, 12 crosses possessed significant and positive estimates.

\section{Grain yield per plant}

Lines GW 322 (0.73) and GW $496(0.65)$ and testers Lok 73 (1.43) and GW 499 (1.34) were reported as good combiners. Estimates of sca effects ranged from $-2.69(\mathrm{GW} 496 \times \mathrm{GW}$ 498) to $2.10(\mathrm{GW} 11 \times \mathrm{GW} 500)$.

Total fifteen characters exhibited significant estimates of sca effects of which, eight possessed significant and positive estimates i.e. in desired direction. 


\section{Biological yield per plant}

For biological yield per plant, lines GW 322 (1.95) and GW 496 (1.30) and testers GW 499 (5.19) and GW 492 (3.24) were found as good combiners. Estimates of sca effects for this character ranged from $-5.02(\mathrm{GW} 322 \times$ GW 504) to $5.61(\mathrm{GW} 366 \times \mathrm{GW} 504)$.

Out of 19 crosses having significant estimates of sca effects, eleven had positive significant estimates.

\section{Harvest index}

Lines GW 366 (5.14) and testers Lok 73 (7.63) and VA-2015-34 (3.51) were reported as good combiners for harvest index. The estimates of sca effects ranged from -9.51 (GW $366 \times$ GW 504) to 9.48 (GW $322 \times$ VA2015-34) for this trait. Seven crosses possessed significant and positive estimates of sca effect.

\section{Protein content}

For protein content, lines GW $366(0.49)$ and GW 322 (0.48) and testers VA-2015-41 (0.87) and GW 500 (0.73) were reported as good combiners. Estimates of sca effects ranged from $-1.38(\mathrm{GW} 11 \times \mathrm{VA}-2015-11)$ to $1.87(\mathrm{GW} 11 \times \mathrm{GW} 500)$.

Total twenty two crosses possessed significant estimates of $s c a$ effects of which, 10 crosses possessed positive and significant estimates.

\section{Hectolitre weight}

Lines GW 451 (1.18) and GW 366 and testers GW 499 (1.76) and GW 498 (1.41) were found as good combiners for hectolitre weight. Estimates of sca effects ranged from $3.16(\mathrm{GW} 322 \times \mathrm{GW} 499)$ to $3.26(\mathrm{GW} 451 \times$ GW 499). Total sixteen crosses exhibited significant estimates of sca effects of which,
10 crosses possessed positive and significant estimates of sca effect. From the potence ratio, it is clear that all the characters were under the influence of non-additive gene action.

The characters days to $50 \%$ heading, days to maturity, plant height, length of main spike, no. of spikelets per main spike, 100-grain weight, protein content and hectolitre weight had above unity estimates of average degree of dominance ratio, which revealed over dominance behavior of interacting alleles.

For characters, no. of effective tillers per plant, grain yield per plant, biological yield per plant and harvest index possessed below unity estimate of average degree of dominance ratio, which suggested partialdominance behavior of interacting alleles.

Since, partial-dominance gene action is involved for inheritance of grain yield per plant and biological yield per plant, isolating transgressive segregants by various breeding procedures would be better option rather than heterosis breeding.

Preponderance of non-additive gene action for characters days to $50 \%$ heading, days to maturity were reported by Kumar et al., (2003), Mandal and Madhuri (2016). Preponderance of non-additive gene action was reported by Dholariya et al., (2014) and Patel (2017) for characters plant height, number of effective tillers per plant and length of main spike.

Pansuriya et al., (2014) reported preponderance of non-additive gene action for number of spikelets per main spike and number of effective tillers per plant. Singh and Singh (2003) and Dholariya et al., (2014) reported major role of non-additive gene action in inheritance of 100-grain weight and grain yield per plant (Table 1 and 2). 
Table.1 Analysis of variance for combining ability and estimates of components of genetic variance for various traits

\begin{tabular}{|c|c|c|c|c|c|c|c|c|c|c|c|c|c|}
\hline $\begin{array}{l}\text { Source of } \\
\text { variation }\end{array}$ & df & $\begin{array}{c}\text { Days to } \\
50 \% \\
\text { heading }\end{array}$ & $\begin{array}{l}\text { Days to } \\
\text { maturity }\end{array}$ & $\begin{array}{c}\text { Plant } \\
\text { height }\end{array}$ & $\begin{array}{c}\text { No. of } \\
\text { effective } \\
\text { tillers per } \\
\text { plant }\end{array}$ & $\begin{array}{c}\text { Length } \\
\text { of } \\
\text { main } \\
\text { spike }\end{array}$ & $\begin{array}{c}\text { No. of } \\
\text { spikelets } \\
\text { per main } \\
\text { spike }\end{array}$ & $\begin{array}{c}\text { 100- } \\
\text { grain } \\
\text { weight }\end{array}$ & $\begin{array}{c}\text { Grain } \\
\text { yield } \\
\text { per } \\
\text { plant }\end{array}$ & $\begin{array}{c}\text { Bio } \\
\text { logical } \\
\text { yield } \\
\text { per } \\
\text { plant }\end{array}$ & $\begin{array}{c}\text { Harvest } \\
\text { index }\end{array}$ & $\begin{array}{l}\text { Protein } \\
\text { content }\end{array}$ & $\begin{array}{c}\text { Hecto } \\
\text { litre } \\
\text { weight }\end{array}$ \\
\hline Replications & 2 & 0.35 & 3.53 & $80.41 *$ & 3.34 & $14.77 * *$ & $10.76^{*}$ & $1.31 * *$ & 4.60 & $56.06^{* *}$ & 40.11 & $4.92 *$ & 6.00 \\
\hline Lines & 4 & $128.26^{* *}$ & $215.65^{* *}$ & $240.92 * *$ & $29.96 * *$ & $6.43 * *$ & $46.89 * *$ & $1.60 * *$ & $37.12 * *$ & $92.88 * *$ & $338.84 * *$ & $7.97 * *$ & $32.31 * *$ \\
\hline Testers & 9 & $21.93 * *$ & $51.24 * *$ & $223.01 * *$ & $24.77 * *$ & $4.04 * *$ & $18.43 * *$ & $1.00 * *$ & $14.26 * *$ & $104.45^{* *}$ & $196.52 * *$ & $4.21 * *$ & $20.99 * *$ \\
\hline Lines $\times$ Testers & 36 & $29.10 * *$ & $62.51 * *$ & $121.16^{* *}$ & $6.64 * *$ & $3.26 * *$ & $8.49 * *$ & $0.45 * *$ & $4.76^{* *}$ & $20.82 * *$ & $74.61 * *$ & $2.58 * *$ & $9.56^{* *}$ \\
\hline Error & 98 & 3.14 & 12.76 & 21.61 & 2.22 & 0.48 & 1.07 & 0.11 & 1.59 & 5.55 & 29.61 & 0.48 & 4.35 \\
\hline \multicolumn{14}{|c|}{ Components of genetic variance } \\
\hline$\sigma_{g c a}^{2}$ (lines) & - & $3.31 *$ & $5.10 *$ & 3.99 & $0.78 *$ & 0.11 & $1.28 *$ & $0.04 *$ & $1.08 *$ & $2.40 *$ & $8.81 *$ & $0.18^{*}$ & $0.76^{*}$ \\
\hline$\sigma_{g c a}^{2}($ testers $)$ & - & -0.48 & -0.75 & 6.79 & $1.21^{*}$ & 0.05 & $0.66^{*}$ & $0.04 *$ & $0.63^{*}$ & $5.58^{*}$ & $8.13^{*}$ & 0.11 & $0.76^{*}$ \\
\hline$\sigma_{g c a}^{2}$ (average) & - & 2.04 & 3.15 & 4.92 & $0.92 *$ & 0.09 & 1.07 & 0.04 & $0.93 *$ & $3.46^{*}$ & 8.58 & 0.16 & 0.76 \\
\hline$\sigma_{s c a}^{2}$ & - & $8.65^{*}$ & $16.58^{*}$ & $33.18^{*}$ & $1.47 *$ & $0.93^{*}$ & $2.47^{*}$ & $0.12 *$ & $1.06^{*}$ & $5.09 *$ & $15.00^{*}$ & $0.70^{*}$ & $1.74 *$ \\
\hline $\begin{array}{l}\text { Potence ratio } \\
\left(\sigma^{2} g c a / \sigma^{2} s c a\right)\end{array}$ & - & 0.24 & 0.19 & 0.15 & 0.62 & 0.09 & 0.43 & 0.32 & 0.88 & 0.68 & 0.57 & 0.22 & 0.44 \\
\hline$\sigma_{A}^{2}$ & - & 4.09 & 6.31 & 9.85 & 1.84 & 0.18 & 2.15 & 0.07 & 1.86 & 6.92 & 17.16 & 0.31 & 1.52 \\
\hline$\sigma_{D}^{2}$ & - & 8.65 & 16.58 & 33.18 & 1.47 & 0.93 & 2.47 & 0.12 & 1.06 & 5.09 & 15.00 & 0.70 & 1.74 \\
\hline$\left(\sigma_{D}^{2} / \sigma_{A}^{2}\right)^{0.5}$ & - & 1.45 & 1.62 & 1.84 & 0.89 & 2.30 & 1.07 & 1.24 & 0.75 & 0.86 & 0.93 & 1.50 & 1.07 \\
\hline
\end{tabular}


Table.2 Estimates of general combining ability (GCA) effect of parents on days to $50 \%$ heading, days to maturity, plant height, number of effective tillers per plant, length of main spike and number of spikelets per main spike

\begin{tabular}{|c|c|c|c|c|c|c|c|c|c|c|c|c|c|}
\hline $\begin{array}{l}\text { Sr. } \\
\text { No. }\end{array}$ & Parents & $\begin{array}{c}\text { Days to } \\
50 \% \\
\text { heading }\end{array}$ & $\begin{array}{l}\text { Days to } \\
\text { maturity }\end{array}$ & $\begin{array}{c}\text { Plant } \\
\text { height }\end{array}$ & $\begin{array}{c}\text { Number } \\
\text { of } \\
\text { effective } \\
\text { tillers } \\
\text { per plant }\end{array}$ & $\begin{array}{c}\text { Length } \\
\text { of main } \\
\text { spike }\end{array}$ & $\begin{array}{c}\begin{array}{c}\text { Number } \\
\text { of }\end{array} \\
\text { spikelets } \\
\text { per main } \\
\text { spike }\end{array}$ & $\begin{array}{c}\text { 100- } \\
\text { grain } \\
\text { weight }\end{array}$ & $\begin{array}{c}\text { Grain } \\
\text { yield } \\
\text { per } \\
\text { plant }\end{array}$ & $\begin{array}{c}\text { Bio } \\
\text { logical } \\
\text { yield } \\
\text { per } \\
\text { plant }\end{array}$ & $\begin{array}{c}\text { Harvest } \\
\text { index }\end{array}$ & $\begin{array}{l}\text { Protein } \\
\text { content }\end{array}$ & $\begin{array}{c}\text { Hecto } \\
\text { liter } \\
\text { weight }\end{array}$ \\
\hline & \multicolumn{7}{|l|}{ Lines } & & & & & & \\
\hline 1 & GW 496 & 0.16 & 0.10 & $4.50^{* *}$ & $0.69 * *$ & $0.54 * *$ & 0.13 & -0.04 & $0.65 * *$ & $1.30 * *$ & -0.22 & $-0.24 *$ & -0.05 \\
\hline 2 & GW 322 & $2.76^{* *}$ & $3.53 * *$ & -0.08 & $0.65^{* *}$ & $0.40 * *$ & $1.95 * *$ & -0.08 & $0.73^{* *}$ & $1.95 * *$ & -0.23 & $0.48 * *$ & -0.58 \\
\hline 3 & GW 366 & $-2.04 * *$ & $-2.57 * *$ & $-1.75 * *$ & $-0.88 * *$ & $-0.55 * *$ & $-1.36^{* *}$ & $0.23 * *$ & $0.40 *$ & $-1.94 * *$ & $5.14 * *$ & $0.49 * *$ & $0.83 * *$ \\
\hline 4 & GW 451 & $-2.01 * *$ & $-2.67 * *$ & $-2.96 * *$ & $0.83 * *$ & $-0.30 * *$ & $-0.76 * *$ & $0.22 * *$ & 0.17 & 0.41 & -0.39 & -0.01 & $1.18^{* *}$ \\
\hline \multirow[t]{4}{*}{5} & GW 11 & $1.13^{* *}$ & $1.60 * *$ & 0.29 & $-1.28^{* *}$ & -0.09 & 0.04 & $-0.33 * *$ & $-1.95 * *$ & $-1.72 * *$ & $-4.30 * *$ & $-0.73 * *$ & $-1.37 * *$ \\
\hline & S.E. (gi) \pm & 0.25 & 0.51 & 0.67 & 0.21 & 0.10 & 0.15 & 0.05 & 0.18 & 0.34 & 0.78 & 0.10 & 0.30 \\
\hline & C.D. at $5 \%$ & 0.49 & 1.00 & 1.31 & 0.41 & 0.20 & 0.29 & 0.10 & 0.35 & 0.67 & 1.53 & 0.20 & 0.59 \\
\hline & \multicolumn{7}{|l|}{ Testers } & & & & & & \\
\hline 1 & GW 480 & 0.06 & -0.67 & $-7.07 * *$ & $-0.71 *$ & $0.44 * *$ & 0.25 & -0.12 & $-1.00 * *$ & $-1.50 * *$ & -0.88 & -0.24 & -0.55 \\
\hline 2 & GW 492 & $-2.61 * *$ & $-3.33 * *$ & 0.59 & $1.87 * *$ & $-0.75 * *$ & $-0.68 * *$ & $0.34 * *$ & 0.24 & $3.24 * *$ & $-4.51 * *$ & 0.15 & $1.10 *$ \\
\hline 3 & GW 498 & $-1.21 * *$ & $-2.33 * *$ & 0.71 & $1.39 * *$ & -0.25 & $-2.06^{* *}$ & $0.33 * *$ & $0.80 * *$ & $2.45^{* *}$ & -1.37 & $0.44 * *$ & $1.41 * *$ \\
\hline 4 & VA-2015-11 & $1.13^{* *}$ & $2.27 * *$ & $3.62 * *$ & $-1.39 * *$ & $0.39 * *$ & 0.38 & -0.11 & $-0.83 * *$ & $-2.40 * *$ & 0.89 & -0.26 & -0.51 \\
\hline 5 & VA-2015-41 & -0.07 & 0.53 & $4.76^{* *}$ & $-0.73 *$ & $\mathbf{0 . 5 5} * *$ & $1.84 * *$ & 0.02 & -0.48 & $-1.84 * *$ & 1.06 & $0.87 * *$ & 0.30 \\
\hline 6 & Lok 73 & $1.33 * *$ & 1.40 & $-3.80 * *$ & -0.61 & $-0.57 * *$ & -0.20 & -0.12 & $1.43 * *$ & $-1.29 *$ & $7.63 * *$ & -0.14 & -0.39 \\
\hline 7 & GW 504 & -0.41 & -0.93 & 1.81 & -0.02 & $-0.45^{* *}$ & 0.22 & $-0.23^{* *}$ & -0.11 & -0.49 & 0.34 & $-0.65 * *$ & -0.77 \\
\hline 8 & GW 499 & 0.66 & 0.27 & 0.43 & $2.07 * *$ & 0.78** & $-0.76^{* *}$ & $0.34 * *$ & $1.34 * *$ & $5.19 * *$ & $-3.64 * *$ & $-0.32 *$ & $1.76^{* *}$ \\
\hline 9 & GW 500 & -0.01 & 0.53 & $-4.32 * *$ & $-0.82^{*}$ & -0.01 & -0.39 & $-0.40 * *$ & $-1.44 * *$ & $-1.26^{*}$ & $-3.03 * *$ & $0.73 * *$ & $-2.21 * *$ \\
\hline \multirow[t]{3}{*}{10} & VA-2015-34 & $1.13 * *$ & $2.27 * *$ & $3.27 * *$ & $-1.05^{* *}$ & -0.11 & $1.40 * *$ & -0.05 & 0.06 & $-2.09 * *$ & $3.51 * *$ & $-0.59 * *$ & -0.13 \\
\hline & S.E. (gi) \pm & 0.38 & 0.77 & 1.00 & 0.32 & 0.15 & 0.22 & 0.07 & 0.27 & 0.51 & 1.17 & 0.15 & 0.45 \\
\hline & C.D. at $5 \%$ & 0.74 & 1.51 & 1.96 & 0.63 & 0.29 & 0.43 & 0.14 & 0.53 & 1.00 & 2.29 & 0.29 & 0.88 \\
\hline
\end{tabular}

*, **, Significant at 0.05 and 0.01 levels of probability, respectively 
Preponderance of non-additive gene action for characters Biological yield per plant and harvest index was reported by Patel (2017) and Tabassum et al., (2017). Singh et al., (2012) reported major role of non-additive gene action in inheritance of protein content and hectolitre weight.

\section{References}

Anonymous, 2018. Annual report of Ministry of Agriculture and Farmers Welfare, 2017-18.

Braun, H. J., Atlin, G., and Payne, T. (2010). Multi-location testing as a tool to identify plant response to global climate change. In: Raynolds CRP (ed), Climate Change and Crop Production, CABI, London, UK.

Comstock, R. E., and Robinson, H. E. (1952). Genetic parameters, their estimation and significance. Proceedings $6^{\text {th }}$ International Grassland Congress, 1, 284-291.

Dholariya, N. D., Akbari, V. R., Patel, J. V., and Chovatia V. P. (2014). Combining ability and gene action study for grain yield and its attributing traits in bread wheat. Electronic Journal of Plant Breeding, 5 (3), 402-407.

Kempthorne, O. (1957). An Introduction to Genetic Statistics. John Willey and Sons. New York.

Kumar, A., Thakur, K. S., Sethi, G. S., and Bhandari, J. C. (2003). Combining ability analysis for grain yield and some other morpho-physiological traits in winter $\times$ spring wheat hybrids. Crop
Research, 26, 334-338.

Mandal, A. B., and Madhuri, G. (2016). Combining Ability Analysis for Morphological and Yield Traits in Wheat (Triticum aestivum). Journal of Plant Science Research, 2016, 3 (2), 157.

Panse, V. G., and Sukhatme, P. V. (1978). Statistical Methods for Agricultural Workers, ICAR, New Delhi.

Pansuriya, A. G., Dhaluk, L. K., Vanpariya, L. G., Savaliya, J. J., Patel, M. B., and Mehta D. R., (2014). Combining ability over environments for grain yield and its components in bread wheat (Triticum aestivum L.). International e. Journal, 3 (1), 36-46.

Patel, H. N. (2017). Combining ability analysis for yield and its components in bread wheat. Electronic Journal of Plant Breeding, 8 (2), 404-408.

Singh, A., Kumar, A., Ahmad, E., Swati, and Jaiswal, J. P. (2012). Combining ability and gene action studies for seed yield, its components and quality traits in bread wheat (Triticum aestivum L.). Electronic Journal of Plant Breeding, 3 (4), 964-972.

Singh, K. H., and Singh, T. B. (2003). Combining ability and heterosis in wheat. Indian J. Agric. Res., 37 (4), 274-278.

Tabassum, Anil, K., and Birendra, P. (2017). Study of Combining Ability and Nature of Gene Action for Yield and Its Contributing Traits in Bread Wheat (Triticum aestivum L. em Thell). Int.J.Curr.Microbiol.App.Sci., 6 (10), 3562-3573.

\section{How to cite this article:}

Parthik U. Patel, B. C. Patel, Mayank P. Sidapara and Deepak D. Sharma. 2020. Combining Ability and Gene Action Studies for Yield and its Component Traits in Bread Wheat (Triticum aestivum L.). Int.J.Curr.Microbiol.App.Sci. 9(05): 2463-2469.

doi: https://doi.org/10.20546/ijcmas.2020.905.282 